DOI 10. $18307 / 2021.0608$

(C) 2021 by Journal of Lake Sciences

\title{
喀斯特水库水化学特征及对无机碳沉积通量的指示”
}

\author{
马 松 ${ }^{1,2}$, 魏 榆 ${ }^{1,2}$, 韩翠红 ${ }^{1,2}$, 晏 浩 $^{1}$, 刘再华 ${ }^{* *}$, 孙海龙 ${ }^{1}$, 鲍 乾 ${ }^{1,2}$ \\ (1: 中国科学院地球化学研究所环境地球化学国家重点实验室,贵阳 550002) \\ (2: 中国科学院大学, 北京 100049)
}

\begin{abstract}
摘 要: 为探究筑坝后不同水库物理、化学、生物过程对水化学和碳循环的影响, 本研究对贵州三岔河流域的平寨水库、 普定水库以及猫跳河流域的红枫湖水库进行研究, 于 2018 年 3 月- 2019 年 1 月分别在人库河流和库区采集了分层水样 和沉降颗粒物, 并探究水中主要离子及颗粒物通量的时空变化特征及其控制因素. 结果表明,水体主要离子的主要来源 受碳酸盐溶解影响, 并且离子浓度受光合作用控制. 红枫湖水库水体水化学类型为 $\mathrm{Ca}-\mathrm{Mg}-\mathrm{HCO}_{3}-\mathrm{SO}_{4}$ 型, 普定水库、平寨 水库水化学类型均为 $\mathrm{Ca}-\mathrm{HCO}_{3}-\mathrm{SO}_{4}$. 夏季藻类光合作用诱导碳酸盐沉淀导致水体表层 $\mathrm{Ca}^{2+} 、 \mathrm{HCO}_{3}^{-}$及溶解态 $\mathrm{Si}$ 浓度降低, 其降低幅度分别为 $20.87 \% \sim 44.25 \% 、 33.12 \% \sim 51.18 \% 、 48.55 \% \sim 96.34 \%$. 此外, 藻类光合作用也影响 C、N、Si 等生源要素 间的化学计量关系. $\mathrm{Mg}^{2+} / \mathrm{Ca}^{2+}$ 比值在水体垂向剖面上主要受碳酸钙沉淀的控制, 而在不同水库之间则主要受流域岩性 的控制. 根据沉积物捕获器通量计算的平寨水库、普定水库、红枫湖水库夏季颗粒无机碳沉积通量分别为 $0.74 、 1.36 、 0.27$ $\mathrm{t} /\left(\mathrm{km}^{2} \cdot \mathrm{d}\right)$, 而根据水体 $\mathrm{Ca}^{2+}$ 浓度降低计算的通量分别为 $0.31 \sim 0.64 、 0.35 \sim 0.99 、 0.09 \sim 0.29 \mathrm{t} /\left(\mathrm{km}^{2} \cdot \mathrm{d}\right)$, 根据水体 $\mathrm{HCO}_{3}^{-}$ 浓度降低计算的通量分别为 $0.30 \sim 0.65 、 0.29 \sim 1.26 、 0.12 \sim 0.33 \mathrm{t} /\left(\mathrm{km}^{2} \cdot \mathrm{d}\right)$. 其红枫湖水库无机碳沉降通量的实测值与计 算值接近,而平寨、普定水库实际沉降通量高于计算值,这可能是有外源输人导致. 因此,利用水化学分层数据能对喀斯 特水库中的无机碳沉降通量进行合理估算,并且能够得到较好的估算结果, 从而指示碳循环的过程.
\end{abstract}

关键词: 水化学; 喀斯特梯级水库; 碳酸钻沉淀; 碳循环; 平寨水库; 普定水库; 红枫湖水库

\section{Hydrochemical characteristics in karst reservoirs and its implication for inorganic carbon deposition fluxes*}

\author{
Ma Song ${ }^{1,2}$, Wei Yu ${ }^{1,2}$, Han Cuihong ${ }^{1,2}$, Yan Hao ${ }^{1}$, Liu Zaihua ${ }^{1 * *}$, Sun Hailong ${ }^{1}$ \& Bao Qian ${ }^{1,2}$ \\ (1: State Key Laboratory of Environmental Geochemistry, Institute of Geochemistry, Chinese Academy of Sciences, Guiyang \\ 550002, P.R.China) \\ (2: University of Chinese Academy of Sciences, Beijing 100049, P.R.China)
}

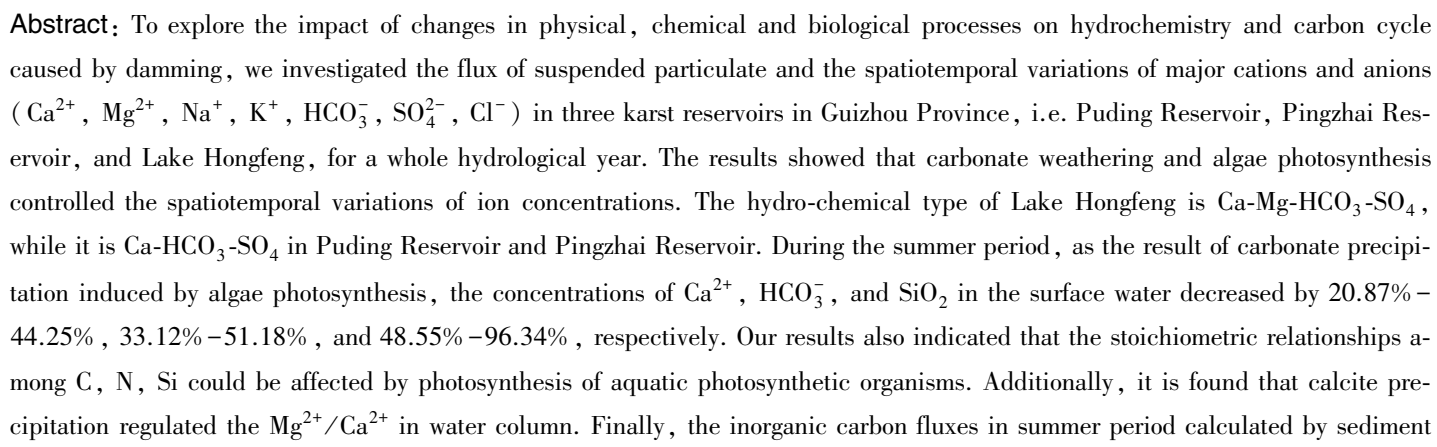

* 2020-11-19 收稿;2021-03-05 收修改稿.

国家自然科学基金委员会-贵州喀斯特科学研究中心联合基金重大项目 (U1612441) 和国家自然科学基金项目 (41673019，41977298) 联合资助.

** 通信作者; E-mail:liuzaihua@ vip.gyig.ac.cn. 
traps were $0.74 \mathrm{t} /\left(\mathrm{km}^{2} \cdot \mathrm{d}\right), 1.36 \mathrm{t} /\left(\mathrm{km}^{2} \cdot \mathrm{d}\right), 0.27 \mathrm{t} /\left(\mathrm{km}^{2} \cdot \mathrm{d}\right)$ for Pingzhai Reservoir, Puding Reservoir and respectively, which are comparable with the fluxes estimated by the concentration differences in $\mathrm{Ca}^{2+}$ and $\mathrm{HCO}_{3}^{-}$between surface and bottom water layers. The measured fluxes of inorganic carbon in Pingzhai Reservoir and Puding Reservoir by sediment traps are higher than the calculated one, suggesting a certain amount of allochthonous inorganic carbon input due to the strong hydrological condition. Therefore, it is an alternative way to estimate the deposition flux of inorganic carbon in karst reservoirs by using vertical variations in ion concentrations in stratification period.

Keywords: Hydrochemistry; cascade reservoirs; calcium carbonate precipitation; carbon cycle; Puding Reservoir; Pingzhai Reservoir; Lake Hongfeng

河流是陆地碳库向海洋碳库输送的重要通道, 目前 $70 \%$ 的自然河流受到筑坝活动的影响. 筑坝显著破 坏了河流的自然连通性, 河流水体出现 “陈化现象”, 水库蓄水的滞留时间可以从数天到数年, 这使得河流水 体的平均滞留时间大大延长 ${ }^{[1]}$. 一般地, 自然状态下的大陆径流的平均滞留时间为 $16 \sim 26 \mathrm{~d}$, 而根据对调蓄 河流的统计表明, 筑坝河流的水体平均滞留时间达到 $60 \mathrm{~d}^{[1]}$. 筑坝改变了自然河流的物质循环 ( 拦截生源 元素、增加碳埋藏和泥沙堆积)、水化学特征及生物群落结构 ${ }^{[2-7]}$. 河流水化学参数是研究地表水重要的地球 化学指标, 可以指示物理、化学、生物过程以及人类活动等对地表水体的影响 ${ }^{[3]}$. Gibbs 将地表水系统划分为 蒸发浓缩、岩石风化、降雨控制三类过程控制 ${ }^{\left[{ }^{[}\right]} ; \mathrm{Hu}$ 等研究了中国两大河流的水化学特征, 表明其主要受到 碳酸盐和蒸发岩溶解作用的影响 ${ }^{[9]}$; Torres 等在安第斯-亚马逊流域的水化学研究表明构造活动作用增强岩 石风化 ${ }^{[10]}$; 张飞等在青海湖的研究表明水化学受自生碳酸盐沉淀的影响 ${ }^{[11]}$; De Montety 等研究表明水化学 不仅受到碳酸盐溶解的控制, 还受浮游植物光合作用的影响 ${ }^{[2-19]}$. 在地表水循环过程中无机碳和有机碳的 转化会影响水化学参数, 可以利用水化学指标计算地表水体的二氧化碳分压 $\left(p \mathrm{CO}_{2}\right)$ 和方解石饱和指数 (SIc), 以此来判断水库水体是 $\mathrm{CO}_{2}$ 源或汇以及方解石是否可能沉积, 因此利用水库水化学变化可以用来指 示无机碳循环过程.

碳酸盐岩风化消耗大气 $\mathrm{CO}_{2}$ 被认为是全球重要的碳汇, 对全球 $\mathrm{CO}_{2}$ 浓度增加有重要的缓冲作用, 但从地 质历史时间尺度来看碳酸盐岩的风化一沉淀过程净碳汇为零. 刘再华等提出的 “耦联水生光合作用盐酸盐风 化碳汇” 模型, 喀斯特水体中水生植物光合作用利用溶解无机碳( DIC) 形成内源有机碳 (AOC), 同时伴随有 大约等量的碳酸钲沉淀 ${ }^{[18,20]}$, 将无机碳循环和有机碳循环紧密结合起来. Tranvik 在 Ohio 的一个水库中研究 表明, 夏季碳循环过程中 DIC 会减少 $30 \%$, 溶解有机碳 (DOC) +颗粒有机碳 (POC) 减少 $4 \%$, 而沉积物中沉 降 $33 \%$,大气 $\mathrm{CO}_{2}$ 释放 $1 \%$, 说明水库沉积物中有大量的碳沉积可能来源 $\mathrm{DIC}^{[21]}$.

夏季深水型水库水体由于表层与底层水体温度差异, 出现热分层和化学分层. 表层水体受生物光合作 用显著影响, 底层则主要反映补给水库水体原本的水化学特征. 陆地地表水系统 “生物碳原 (BCP)” 效应将 $\mathrm{DIC}$ 光合作用转化为 $\mathrm{AOC}$ 过程中, $\mathrm{HCO}_{3}^{-}$一部分被水生植物光合利用, 另外一部分同 $\mathrm{Ca}^{2+}$ 结合生成方解石, 方解石 $\left(\mathrm{CaCO}_{3}\right)$ 沉淀析出, 水库表层水体中 $\mathrm{Ca}^{2+}-\mathrm{HCO}_{3}^{-}$浓度降低, 因此 $\mathrm{Ca}^{2+}-\mathrm{HCO}_{3}^{-}$的时空变化特征可以反映 “生物碳不” 效应的强度, 同时也可以利用其化学计量关系计算水体析出的方解石沉积通量. 基于碳酸岩溶 解、BCP 效应转化为 AOC 伴随无机碳沉淀过程中的碳转化在水化学特征相互关联研究较少, 本文用水体水 化学中 $\mathrm{Ca}^{2+}-\mathrm{HCO}_{3}^{-}$变化来指示水生植物光合作用导致的方解石沉淀的碳循环过程, 并以此计算无机碳沉积 通量.

本研究选取三岔河流域的平寨水库、普定水库以及猫跳河流域的红枫湖水库进行研究, 采集不同季度 水库水样和悬浮颗粒物样品, 以此来了解喀斯特水库水化学变化以及对碳循环的指示.

\section{1 研究区概况和研究方法}

\section{1 研究区概况}

贵州省位于世界上岩溶发育最复杂、类型最齐全、分布面积最大的东亚岩溶区域,是我国开展岩溶研究 的重要地区, 也是我国受到岩溶石漠化影响制约经济发展最严重的地区 ${ }^{[22-23]}$. 乌江是长江上游最大的支流, 同时也是贵州省第一大河流, 三岔河流域和猫跳河流域是乌江的上游发源地, 研究区的 3 个水库分别属于 三岔河流域的普定水库和平寨水库以及猫跳河流域的红枫湖水库(图 1). 
猫跳河流域全长 $181 \mathrm{~km}$, 流域面积 $1596 \mathrm{~km}^{2}$, 河流总落差 $549.6 \mathrm{~m}$, 地势平坦农业发达; 出露有寒武系、 石炭系、二叠系、三叠系、第三系碳酸盐地层, 属于亚热带温和湿润气候, 年均气温 $13.8^{\circ} \mathrm{C}$, 年均降雨 $1000 \sim$ $1300 \mathrm{~mm}$. 红枫湖水库是猫跳河流域最早建成投人使用的水库, 受到人类活动的影响其富营养化严重 ${ }^{[24-26]}$. 三岔河流域全长 $325.6 \mathrm{~km}$, 河流落差 $1300 \mathrm{~m}$, 流域面积 $7264 \mathrm{~km}^{2[27]}$; 出露有二叠、三叠系灰岩、泥质灰岩、白 云岩、泥质白云岩等碳酸盐间夹带状砂岩、泥页岩及煤系碎屑岩 ${ }^{228]}$, 三岔河流域属于亚热带季风气候, 多年 平均气温 $12 \sim 16^{\circ} \mathrm{C}$, 年均降雨 $1300 \mathrm{~mm}$, 年降雨不均, 丰水期降雨占全年降雨量的 $80 \%$, 枯水期降雨占全年 降雨量的 $20 \%$, 普定水库处于中营养一轻度富营养化状态, 平寨水库处于贫营养化状态 ${ }^{[29]}$.

红枫湖水库 (HFHSK) 最大库容 $6.01 \times 10^{8} \mathrm{~m}^{3}$, 水体滞留时间 $119 \mathrm{~d}$, 水深在 $15 \sim 45 \mathrm{~m}$, 属于深水湖泊型水 库 ${ }^{[25]}$; 普定水库 (PDSK)、平寨水库 (PZSK) 属于河道型水库, 普定水库库容 $3.6 \times 10^{8} \mathrm{~m}^{3}$, 水深 $30 \sim 50 \mathrm{~m}$, 水体 滞留时间 $40.6 \mathrm{~d}^{[30]}$; 平寨水库库容 $10.97 \times 10^{8} \mathrm{~m}^{3}$, 水深 $30 \sim 120 \mathrm{~m}$, 水体滞留时间 $80.4 \mathrm{~d}^{[31]}$. 截至 2020 年红枫 湖水库、普定水库和平寨水库库龄分别为 $60 、 26$ 和 $5 \mathrm{a}$.
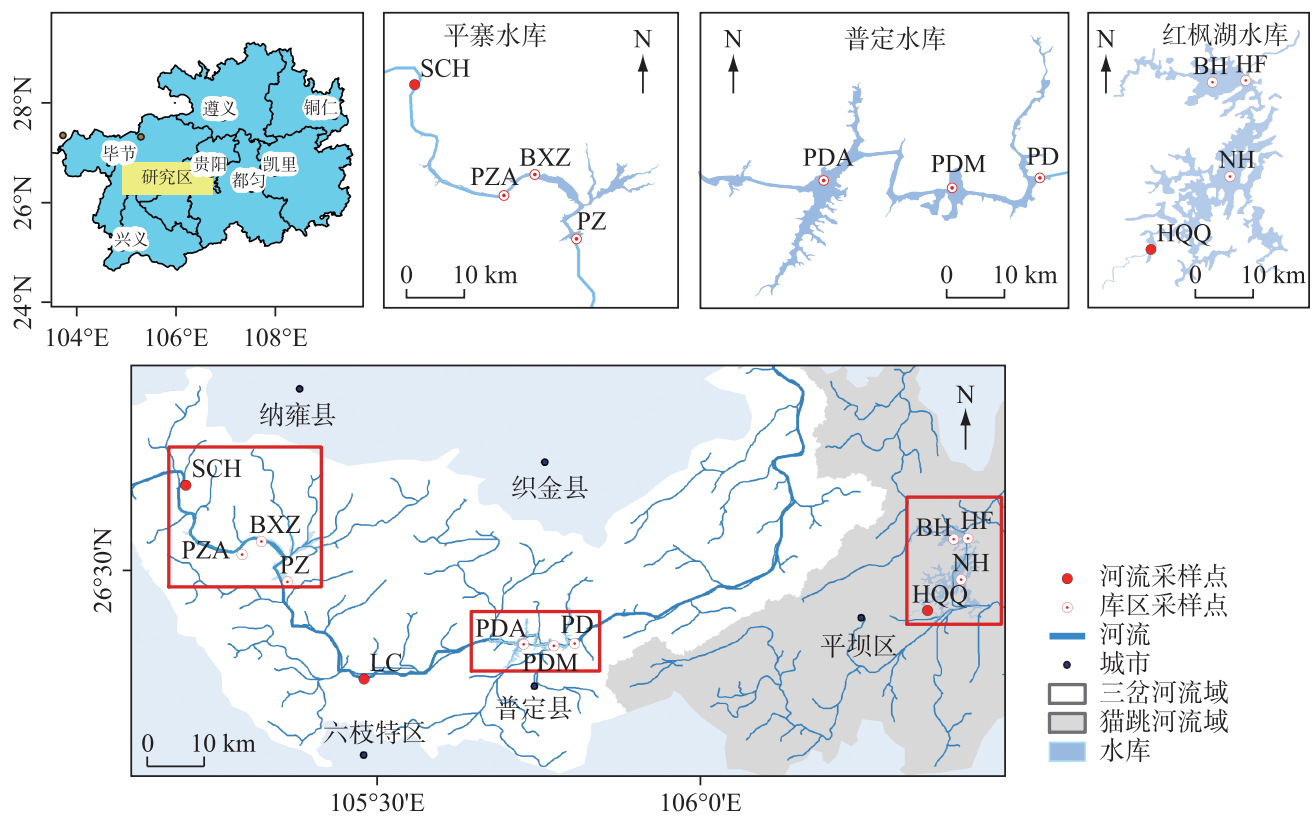

图 1 研究区概况及采样点分布

Fig. 1 The research area and distribution of sampling sites

\section{2 样品采集与分析测试}

2018 年 3 月 -2019 年 1 月对 3 个喀斯特水库进行了 5 次样品的采集,采样间隔时间约 2 个月. 每个水 库内沿河流人口至大坝设置 3 个采样点, 并在上游河流设置 1 个表层水体采样点 (平寨水库 $\mathrm{SCH}$ 、普定水库 LC、红枫湖水库 HQQ) (图 1) ; 水库库区每个采样点根据实际水深, 采集 $0 \sim 0.5 、 10 、 20 、 30 、 40 、 80 、 120 \mathrm{~m}$ 深度 水样, 在水样采集点设计不同深度 $(10 、 20 、 40 \mathrm{~m}$ ) 沉积物采集捕获器 (直径 $14 \mathrm{~cm}$, 长 $140 \mathrm{~cm}$ ). 使用法国 PONSEL ODEON 以及 YSI EXO2 测定水温 $(T)$ 、电导率 $(\mathrm{EC}) 、 \mathrm{pH}$ 、溶解氧 $(\mathrm{DO})$ 等水化学参数, 精度分别为 \pm $0.01{ }^{\circ} \mathrm{C} 、 \pm 0.01 \mu \mathrm{S} / \mathrm{cm} 、 \pm 0.01 、 \pm 0.01 \mathrm{mg} / \mathrm{L}$. 碱度采用德国 MERCK 滴定盒现场滴定, 滴定精度为 $\pm 0.1 \mathrm{mmol} / \mathrm{L}$. 水样经 $0.45 \mu \mathrm{m}$ 的醋酸纤维膜过滤后装人 $25 \mathrm{~mL}$ 高密度聚乙烯瓶中, 用于阳离子 $\left(\mathrm{Ca}^{2+} 、 \mathrm{Mg}^{2+} 、 \mathrm{Sr}^{2+} 、 \mathrm{Na}^{+} 、 \mathrm{~K}^{+}\right)$ 测定的样品加人优级纯浓 $\mathrm{HNO}_{3}$ 酸化至 $\mathrm{pH}<2$, 用于阴离子 $\left(\mathrm{F}^{-} 、 \mathrm{NO}_{3}^{-} 、 \mathrm{Cl}^{-} 、 \mathrm{SO}_{4}^{2-}\right)$ 测定的样品直接密封, 所有样 品带回实验室在分析测试前低温 $\left(4^{\circ} \mathrm{C}\right)$ 保存.

本研究中野外采集的样品带回实验室后通过美国 Dionex 公司生产的 ICS-90 型离子色谱仪进行阴离子 含量的测试, 检测限为 $0.01 \mathrm{mg} / \mathrm{L}$, 相对标准偏差 $<2 \%$; 阳离子含量是通过美国 Varian 公司生产的 Vista MPX 型 ICP-OES 电感耦合等离子体光谱仪进行测定, 检测限为 $0.01 \mathrm{mg} / \mathrm{L}$, 相对标准偏差 $<1 \%$; 使用德国 
Elementar 公司生产的 vario MACRO cube 元素分析仪测定颗粒物有机碳 (OC)、无机碳 (IC) 含量, 检出范围 为 $0 \sim 150 \mathrm{mg}$, 相对标准偏差 $<0.5 \%$. 所有分析测试在中国科学院地球化学研究所环境地球化学国家重点实 验室完成. 水体方解石饱和指数 (SIc) 和二氧化碳分压 $\left(p \mathrm{CO}_{2}\right)$ 使用计算机软件 PHREEQC 计算获得 ${ }^{[32]}$.

\section{2 结果}

\section{1 水化学特征及沉积物通量}

主要水化学、离子浓度等数据见表 1 . 河流和水库 $\mathrm{T} 、 \mathrm{EC} 、 \mathrm{DO} 、 \mathrm{pH}$ 具有明显的时空变化, 受筑坝影响河水 和水库水化学参数差异明显 (图 2). 分层期水库表层水体相对底层水体有高 $\mathrm{DO} 、 \mathrm{~T}$ 和 $\mathrm{pH}$, 低 $\mathrm{EC}$, 混合期表 层和底层无明显差异; 平寨水库 $\mathrm{DO} 、 \mathrm{EC} 、 \mathrm{~T} 、 \mathrm{pH}$ 夏季底层减表层平均值分别为 $-4.14 \mathrm{mg} / \mathrm{L} 、 136.55 \mu \mathrm{S} / \mathrm{cm}$ 、 $-6.30^{\circ} \mathrm{C} 、-1.22$; 普定水库 DO 、 $\mathrm{EC} 、 \mathrm{~T} 、 \mathrm{pH}$ 夏季底层减表层平均值分别为 $-3.60 \mathrm{mg} / \mathrm{L} 、 28.06 \mu \mathrm{S} / \mathrm{cm} 、-6.27^{\circ} \mathrm{C}$ 、 -0.75 ; 红枫湖水库 $\mathrm{DO} 、 \mathrm{EC} 、 \mathrm{~T} 、 \mathrm{pH}$ 夏季底层减表层平均值分别为 $-9.42 \mathrm{mg} / \mathrm{L} 、 94.1 \mu \mathrm{S} / \mathrm{cm} 、-5.28^{\circ} \mathrm{C} 、-1.55$. 3 个水库表层水体 $\mathrm{EC}$ 最小值、最大值分别出现在夏季和冬季; $\mathrm{pH}$ 最大值均出现在夏季, 平寨水库 $\mathrm{pH}$ 最小 值出现在冬季, 普定水库和红枫湖水库 $\mathrm{pH}$ 最小值均出现在秋季; 平寨水库、普定水库和红枫湖水库 $\mathrm{DO}$ (饱 和度) 最大值均出现在夏季 (图 2). 3 个水库底层水体 $\mathrm{EC} 、 \mathrm{pH} 、 \mathrm{DO}$ 最小值均出现在夏季; 平寨水库 $\mathrm{EC}$ 最大 值出现在夏季, 普定水库和红枫湖水库 $\mathrm{EC}$ 最大值均出现在春季; 平寨水库、普定水库和红枫湖水库 $\mathrm{pH}$ 最大 值分别出现在春季、夏季、冬季;平寨水库、普定水库、红枫湖水库 DO 最大值出现在冬季.

3 个水库在春、夏季出现分层, 在分层期间表底层水体水化学参数显著变化, 秋、冬季水体混合时水化学 参数垂向均一;夏季水体分层导致水体底层缺氧, DO 最小值出现在底层水体. 而春、夏季湖水表层 DO 浓度 显著高于河水 DO 浓度, 也远高于饱和浓度, 表明水库表层水体藻类光合作用释氧远高于耗氧; 水库从人库 口至大坝 $\mathrm{EC} 、 \mathrm{pH} 、 \mathrm{DO}$ 有逐渐降低的趋势.

平寨水库、普定水库、红枫湖水库夏季 $(65 \mathrm{~d})$ 沉积通量范围分别为 $584.38 \sim 1811.29 、 1752.37 \sim 3223.21$ 、 181.39 586.87 t/ km ${ }^{2}$, 平均值分别为 $1138.86 、 2577.31 、 329.84 \mathrm{t} / \mathrm{km}^{2}$; 无机碳含量为 $2.32 \% \sim 8.11 \% 、 3.03 \% \sim$ $4.15 \% 、 4.74 \% \sim 6.65 \%$, 平均值分别为 $4.97 \% 、 3.51 \% 、 5.64 \%$; 无机碳沉积通量范围分别为 $40.85 \sim 55.73$ 、 $72.72 \sim 108.33 、 9.73 \sim 28.49 \mathrm{t} / \mathrm{km}^{2}$, 平均值分别为 $48.05 、 88.19 、 17.85 \mathrm{t} / \mathrm{km}^{2}$ (图 3). 普定水库由于捕获器丢失, 只有 1 个采样点捕获器数据. 垂向上, 总沉积通量平寨水库、普定水库有增加的趋势, 而红枫湖水库减少, 从 水库人口至大坝总沉积通量有降低的趋势; 垂向上 IC 含量均降低, 从水库人口至大坝为逐渐增加的趋势; 垂向上, 夏季 IC 沉积通量平寨水库和红枫湖水库均减少, 普定水库增加, IC 含量没有表现出明显差异 (图 $3)$.

$\mathrm{Ca}^{2+}$ 和 $\mathrm{Mg}^{2+}$ 为主要的阳离子, $\mathrm{HCO}_{3}^{-}$和 $\mathrm{SO}_{4}^{2-}$ 为主要的阴离子, 红枫湖水库水体化学类型为 $\mathrm{Ca}-\mathrm{Mg}-\mathrm{HCO}_{3}-$ $\mathrm{SO}_{4}$ 型, 普定、平寨水库水化学类型为 $\mathrm{Ca}-\mathrm{HCO}_{3}-\mathrm{SO}_{4}$ (图 4) ; 总体上不同阳离子浓度高低顺序为 $\mathrm{Ca}^{2+}>\mathrm{Mg}^{2+}>$ $\mathrm{Na}^{+}>\mathrm{K}^{+}$, 阴离子浓度高低顺序为 $\mathrm{HCO}_{3}^{-}>\mathrm{SO}_{4}^{2-}>\mathrm{Cl}^{-}>\mathrm{NO}_{3}^{-}$, 水体离子浓度表现出显著季节变化, 在夏季所有离 子浓度都出现最低值, 分层期间水库表层水体 $\mathrm{Ca}^{2+}$ 浓度出现最小值, 最大值出现在冬季, 河水和湖水变化趋 势一致,离子浓度一般规律为河水 $>$ 水库底层 $\geqslant$ 表层.

\section{2 方解石饱和指数及二氧化碳分压}

红枫湖水库 $3 、 6 、 8$ 月表层 SIc $>0,10 \mathrm{~m}$ 以下水体全年 $\mathrm{SIc}<0$, 其河水只有 1 月 $\mathrm{SIc}<0$. 普定水库湖水表层 10 月 SIc $<0$, 其余月份 SIc $>0,10 \mathrm{~m}$ 以下水体只有 8 月 SIc $>0$, 其河水只有 8 月 SIc $<0$ (表 1 ). 平寨水库湖水表 层 3、6、8、10 月 SIc $>0,10 \mathrm{~m}$ 以下水体 3 月 $\mathrm{SIc}>0$. 平寨水库河流一直处于过饱和状态 $($ 表 1 ).

二氧化碳分压 $\left(p \mathrm{CO}_{2}\right)$ 用于反映水体溶解 $\mathrm{CO}_{2}$ 与大气 $\mathrm{CO}_{2}$ 平衡状态, 判断水体 $\mathrm{CO}_{2}$ 的源或汇. 当水体 $p \mathrm{CO}_{2}$ 高于空气 $p \mathrm{CO}_{2}$ 时, 水体是大气 $\mathrm{CO}_{2}$ 的源; 当水体 $p \mathrm{CO}_{2}$ 低于空气 $p \mathrm{CO}_{2}$ 时, 水体是大气 $\mathrm{CO}_{2}$ 的汇. $\mathrm{HQQ}$ 的 $p \mathrm{CO}_{2}$ 均值 (1223.67 \pm 406.92$) \mu \mathrm{atm} ; \mathrm{LC}$ 的 $p \mathrm{CO}_{2}$ 均值为 (1571.23 4452.10$) \mu \mathrm{atm} ; \mathrm{SCH}$ 的 $p \mathrm{CO}_{2}$ 均值为 (1429.58 \pm 427.51) $\mu \mathrm{atm}, 3$ 条人库河流 $p \mathrm{CO}_{2}$ 均远高于大气 $p \mathrm{CO}_{2}(400 \mu \mathrm{atm})$. 平寨水库、普定水库、红枫湖水库表层水 体 $p \mathrm{CO}_{2}$ 在春、夏季低于大气中的 $p \mathrm{CO}_{2}$, 均表现为大气库 $\mathrm{CO}_{2}$ 的汇, 3 个水库的 $p \mathrm{CO}_{2}$ 均与 $\mathrm{DO}$ 和 SIc 呈负相关 关系. 普定水库春、夏季表层会出现库内水体 $p \mathrm{CO}_{2}$ 高于大气 $p \mathrm{CO}_{2}$ 的情况 (表 1). 


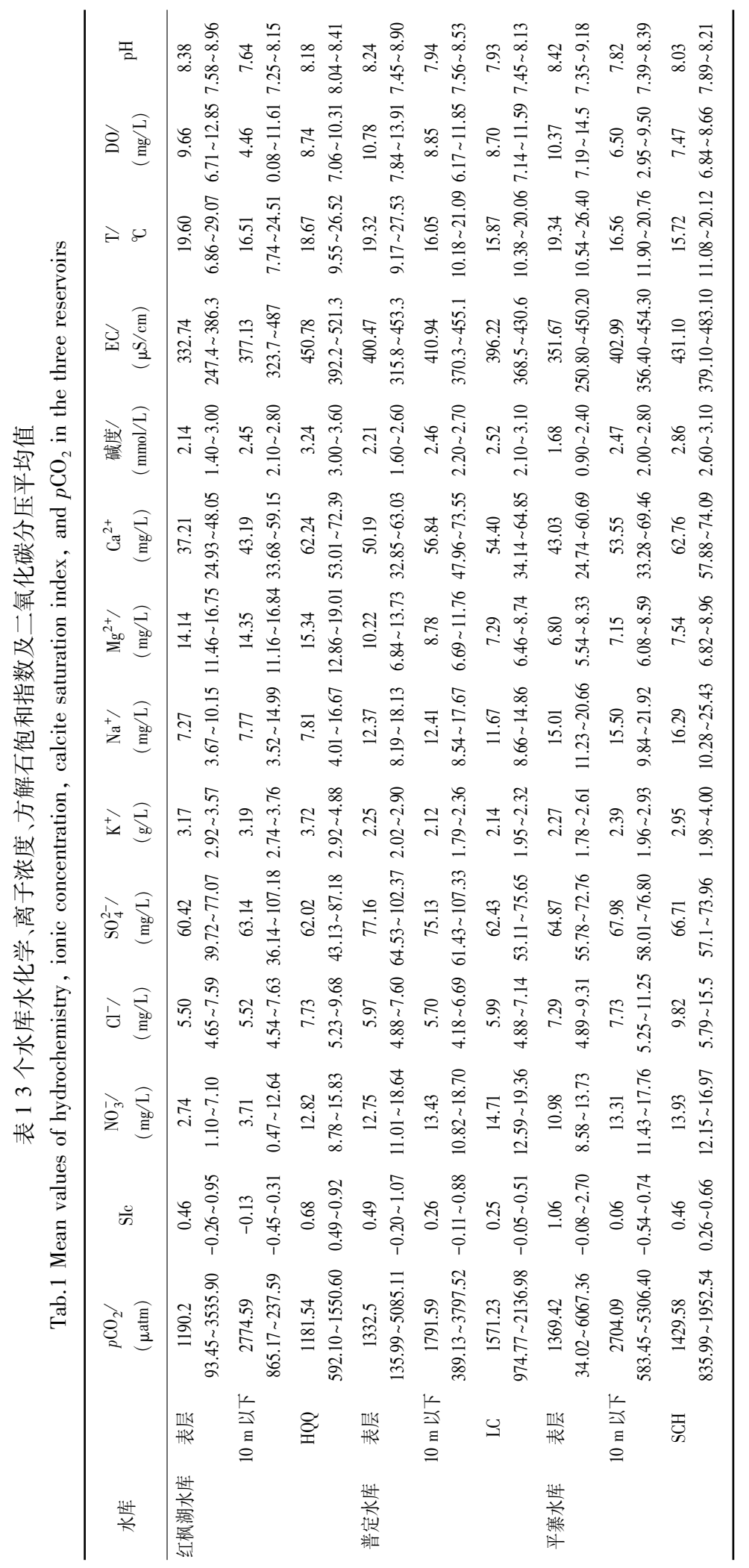



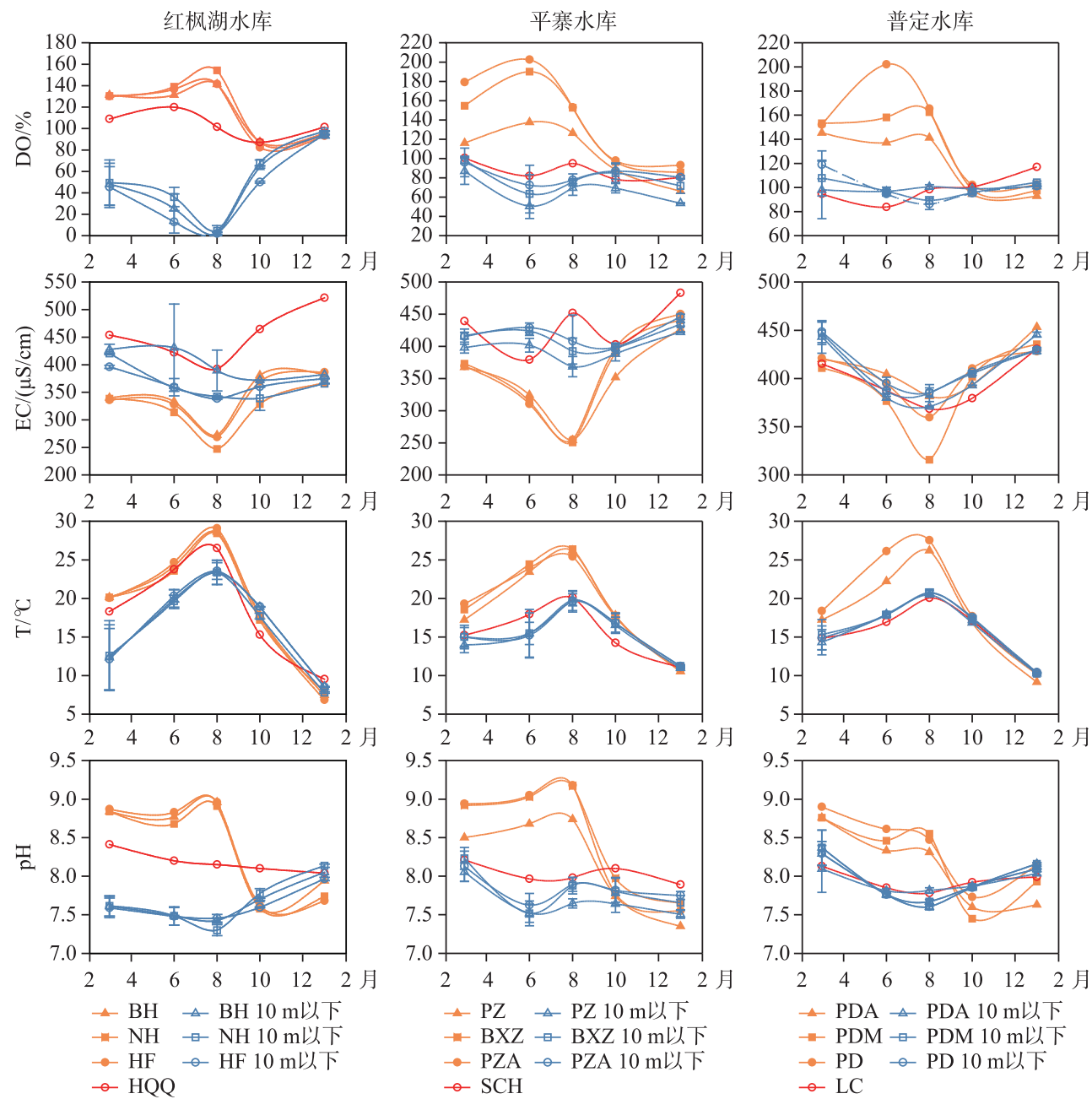

图 2 红枫湖水库、平寨水库和普定水库水化学时空变化 (蓝色有误差棒为平均值)

Fig. 2 Spatial and temporal variations of hydrochemistry in Lake Hongfeng, Pingzhai Reservoir and Puding Reservoir

\section{3 讨论}

\section{1 利用化学计量关系判断水库主要离子来源}

地表水体中主要离子的来源主要包括岩石矿物风化( 碳酸盐岩、硅酸岩、蒸发岩等)、人类活动输人、大 气沉降等. 不同流域水库的主要离子受不同因素控制 (图 4). 韩贵琳等的研究表明在三岔河流域河流水化 学主要受碳酸岩风化作用控制 ${ }^{[23,27]}$, 碳酸盐分别受碳酸和硫酸溶解的化学反应式如下:

$$
\begin{gathered}
2 \mathrm{Ca}_{(x)} \mathrm{Mg}_{(1-x)} \mathrm{CO}_{3}+\mathrm{H}_{2} \mathrm{SO}_{4}=2 x \mathrm{Ca}^{2+}+2(1-x) \mathrm{Mg}^{2+}+2 \mathrm{HCO}_{3}^{-}+\mathrm{SO}_{4}^{2-} \\
\mathrm{Ca}_{(x)} \mathrm{Mg}_{(1-x)} \mathrm{CO}_{3}+\mathrm{H}_{2} \mathrm{O}+\mathrm{CO}_{2}=x \mathrm{Ca}^{2+}+(1-x) \mathrm{Mg}^{2+}+2 \mathrm{HCO}_{3}^{-} \\
\mathrm{Ca}_{(x)} \mathrm{Mg}_{(1-x)} \mathrm{CO}_{3}+\mathrm{H}_{2} \mathrm{O}+\mathrm{CO}_{2}+\mathrm{H}_{2} \mathrm{SO}_{4}=3 x \mathrm{Ca}^{2+}+3(1-x) \mathrm{Mg}^{2+}+4 \mathrm{HCO}_{3}^{-}+\mathrm{SO}_{4}^{2-} \\
\mathrm{CaSO}_{4}=\mathrm{Ca}^{2+}+\mathrm{SO}_{4}^{2-}
\end{gathered}
$$

通过化学计量关系 (公式 (1) (4)) 可知, 在喀斯特地区如果只有碳酸溶解碳酸盐岩, 那么摩尔比值 $\left(\left[\mathrm{Ca}^{2+}\right]+\left[\mathrm{Mg}^{2+}\right]\right):\left[\mathrm{HCO}_{3}^{-}\right]=0.5$, 如果有硫酸参与到碳酸盐溶解, 那么摩尔比值 $\left(\left[\mathrm{Ca}^{2+}\right]+\left[\mathrm{Mg}^{2+}\right]\right)$ : 

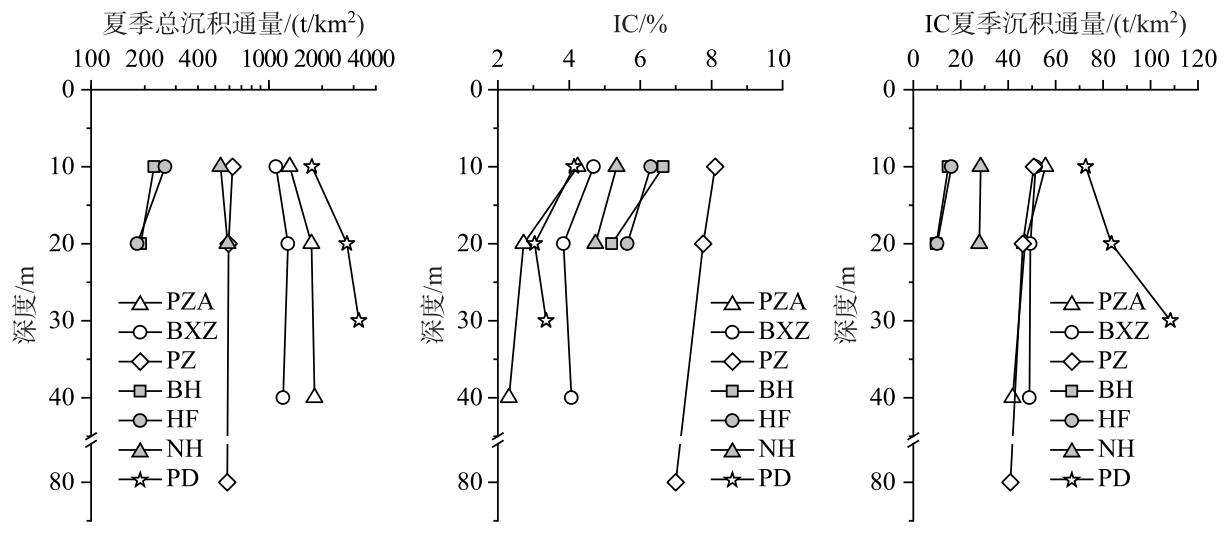

图 3 夏季平寨水库、普定水库、红枫湖水库沉积通量、无机碳含量和无机碳沉积通量

Fig.3 The total sediment fluxes, IC content and IC deposition fluxes in Pingzhai Reservoir, Puding Reservoir and Lake Hongfeng in summer
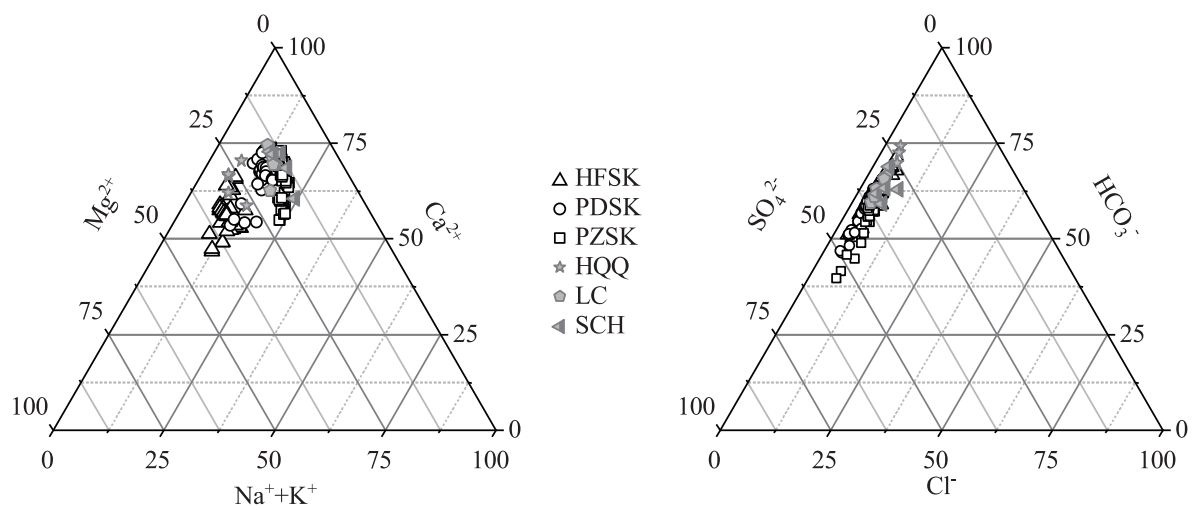

图 4 红枫湖水库、普定水库、平寨水库水化学三角组分图

Fig.4 Ternary diagram of major ions in Lake Hongfeng, Puding Reservoir and Pingzhai Reservoir

$\left[\mathrm{HCO}_{3}^{-}\right]>0.5$. 本研究中, 平寨、普定、红枫湖水库底层水体的 $\left(\left[\mathrm{Ca}^{2+}\right]+\left[\mathrm{Mg}^{2+}\right]\right):\left[\mathrm{HCO}_{3}^{-}\right]$摩尔比值平均值分 别为 $0.68 、 0.74 、 0.71$, 表明水中的 $\mathrm{Ca}^{2+} 、 \mathrm{Mg}^{2+}$ 和 $\mathrm{HCO}_{3}^{-}$可能部分来自于硫酸溶解碳酸盐岩和石膏溶解 ${ }^{[33-35]}$. 水 库底层水化学参数和河流较为一致,表明水库表层水体不是稀释作用导致其表层离子浓度降低. 因此选用 水库的底层水体进行讨论, 水库表层水体的 $\mathrm{Ca}^{2+}$ 和 $\mathrm{HCO}_{3}^{-}$受自生碳酸钙沉淀过程影响巨大, 对 $\left(\left[\mathrm{Ca}^{2+}\right]+\right.$ $\left.\left[\mathrm{Mg}^{2+}\right]\right) /\left[\mathrm{HCO}_{3}^{-}\right]$与 $\left[\mathrm{SO}_{4}^{2-}\right]$ 作相关性分析, 表明普定水库、平寨水库两者呈显著正相关关系 (图 5). 随着 $\mathrm{SO}_{4}^{2-}$ 浓度逐渐增大, $\left(\left[\mathrm{Ca}^{2+}\right]+\left[\mathrm{Mg}^{2+}\right]\right) /\left[\mathrm{HCO}_{3}^{-}\right]$逐步趋近于 1, 也就是硫酸溶解或者石膏溶解的端元值. 同 时, 由图 5 可知, 平寨水库和普定水库水化学组成均受到硫酸溶解或石膏溶解的影响, 其中平寨水库受硫酸 溶解或石膏溶解影响相对较小, 而普定水库受硫酸溶解或石膏溶解影响最大, 贡献甚至超过 $50 \%\left(\left(\left[\mathrm{Ca}^{2+}\right]+\right.\right.$ $\left.\left.\left[\mathrm{Mg}^{2+}\right]\right) /\left[\mathrm{HCO}_{3}^{-}\right]=0.75\right)^{[34]}$.

\section{2 光合作用对水库表层水化学的影响}

自然条件和实验研究表明生物光合作用是诱导方解石沉淀的重要原因之一 ${ }^{[12-13,17]}$. 方解石的化学沉淀 主要受温度、pH、 $\mathrm{Ca}^{2+}$ 浓度、成核位置控制 ${ }^{[13]}$. 表层水体 $\mathrm{EC}$ 与 $\mathrm{Ca}^{2+}$ 呈显著相关关系 $(r=0.861, P<0.01)$, 说 明研究区 $\mathrm{EC}$ 主要受 $\mathrm{Ca}^{2+}$ 浓度变化影响 ${ }^{[36]}, \mathrm{Ca}^{2+}$ 和 $\mathrm{T} 、 \mathrm{pH}$ 显著负相关关系 $(r=-0.710, P<0.01 ; r=-0.504$, $P<0.01$ ), 表层生物光合作用吸收 $\mathrm{CO}_{2}$ ( 公式 (5)), $\mathrm{pH}$ 升高方解石沉淀, 表明方解石沉淀与光合作用有关; 表 层 DO 与 SIc 有显著相关关系 $(r=0.863, P<0.01)$, 表层 DO 与 $p \mathrm{CO}_{2}$ 有显著负相关关系 $(r=-0.818, P<0.01)$ (图 6), 在春夏季湖水 DO 过饱和度, 其 SIc $>0$, 另外春、夏季湖水 DO 过饱和, $p \mathrm{CO}_{2}<400 \mu \mathrm{atm}$, 表明水库表层 


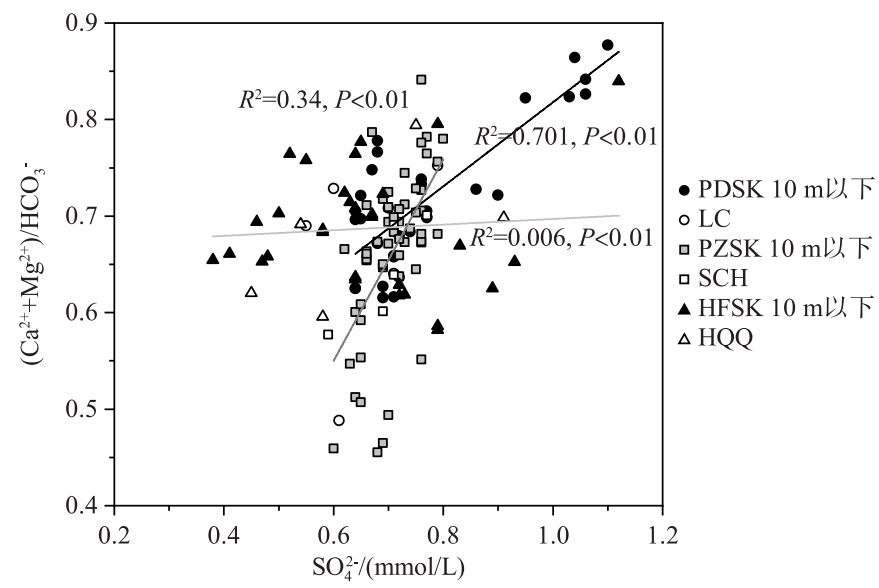

图 53 个水库 $\left(\mathrm{Ca}^{2+}+\mathrm{Mg}^{2+}\right) / \mathrm{HCO}_{3}^{-}$与 $\mathrm{SO}_{4}^{2-}$ 浓度之间的关系

Fig.5 Relationship between $\left(\mathrm{Ca}^{2+}+\mathrm{Mg}^{2+}\right) / \mathrm{HCO}_{3}^{-}$and $\mathrm{SO}_{4}^{2-}$ concentration in three reservoirs

水体中藻类光合作用从大气吸收 $\mathrm{CO}_{2}$, 同时导致 $\mathrm{SIc}>0$, 表明在 3 个水库方解石沉淀主要受藻类光合作用控 制; 方解石沉淀会移除水体中 $\mathrm{Ca}^{2+} 、 \mathrm{HCO}_{3}^{-}$, 同时释放 $\mathrm{CO}_{2}$ (公式 (6)). 因为温跃层出现在 $5 \sim 10 \mathrm{~m}$ 左右的位 置, 另外河流的 $\mathrm{EC}$ 和水库底层 $\mathrm{EC}$ 较为一致, 所以认为水库 $10 \mathrm{~m}$ 以下水体相对稳定, 代表原始河流稀释之 后的结果, 为了衡量表层水体离子浓度变异系数 $\left(C_{\mathrm{V}}\right)$, 表征方解石沉淀对夏季和秋季表层水体中 $\mathrm{Ca}^{2+}$ 的移 除, 公式如下:

$$
\begin{gathered}
\mathrm{CO}_{2}+\mathrm{H}_{2} \mathrm{O} \stackrel{\text { 光合作用 }}{\longrightarrow} \mathrm{CH}_{2} \mathrm{O}+\mathrm{O}_{2} \\
\mathrm{Ca}^{2+}+2 \mathrm{HCO}_{3}^{-} \leftrightarrow \mathrm{CaCO}_{3} \downarrow+\mathrm{H}_{2} \mathrm{O}+\mathrm{CO}_{2} \uparrow \\
2 \mathrm{HCO}_{3}^{-} \leftrightarrow \mathrm{CO}_{2}+\mathrm{CO}_{3}^{2-}+\mathrm{H}_{2} \mathrm{O} \\
C_{\mathrm{V}}=\left((X / \mathrm{Cl})_{\text {below }}-(X / \mathrm{Cl})_{\text {surface }}\right) /\left((X / \mathrm{Cl})_{\text {below }}\right) \times 100 \%
\end{gathered}
$$

式中, $C_{\mathrm{V}}$ 表示某 $X$ 元素表层与底层之差的百分比, $(X / \mathrm{Cl})_{\text {below }}$ 为表层 $10 \mathrm{~m}$ 以下恒温层的平均值, $(X / \mathrm{Cl})_{\text {surface }}$ 为表层水的值, 某 $X$ 元素比 $\mathrm{Cl}^{-}$的浓度消除河水稀释的影响, 单位为 $\mathrm{mmol} / \mathrm{L}$; 湖水夏季表层、底层水体 $\mathrm{Ca}^{2+}$ 、 $\mathrm{Mg}^{2+} 、 \mathrm{~K}^{+} 、 \mathrm{Na}^{+} 、 \mathrm{HCO}_{3}^{-} 、 \mathrm{SO}_{4}^{2-} 、 \mathrm{NO}_{3}^{-} 、 \mathrm{SiO}_{2}$ 离子浓度差异 (表 2) ; 如图 7 所示夏季因碳酸钻沉淀导致表层水体 $\mathrm{Ca}^{2+} 、 \mathrm{HCO}_{3}^{-}$移除达 $20.87 \% \sim 44.25 \% 、 33.12 \% \sim 51.18 \%$, 水库硅藻利用硅的移除达 $48.55 \% \sim 96.34 \%{ }^{[37]}$. 夏季 水库表层 $\mathrm{Ca}^{2+}$ 变幅为普定水库 $(41.62 \% \pm 2.75 \%)>$ 红枫湖水库 $(32.25 \% \pm 3.92 \%)>$ 平寨水库 $(31.38 \% \pm$ $8.06 \%)$, 生物光合作用诱导方解石的沉淀影响表层水体水化学参数. 在冬季水体 $\mathrm{Ca}^{2+}$ 变异系数平寨水库> 普定水库 $>$ 红枫湖水库; 普定水库为 $-2.74 \% \pm 2.35 \%$, 红枫湖水库为 $-0.94 \% \pm 0.55 \%$, 平寨水库为 $-3.31 \% \pm$ $0.92 \%$,夏季表层生物光合诱导方解石沉积对水化学影响不可忽视.

表 2 夏季主要离子表层和底层变异系数 $(\%)$

Tab.2 Coefficients of variation in the concentrations of major ions between surface and bottom water layers

\begin{tabular}{cccccccccccc}
\hline 水库 & $\mathrm{HCO}_{3}^{-}$ & $\mathrm{Ca}^{2+}$ & $\mathrm{K}^{+}$ & $\mathrm{Mg}^{2+}$ & $\mathrm{Na}^{+}$ & $\mathrm{SiO}_{2}$ & $\mathrm{Sr}^{2+}$ & $\mathrm{F}^{-}$ & $\mathrm{Cl}$ & $\mathrm{NO}_{3}^{-}$ & $\mathrm{SO}_{4}^{2-}$ \\
\hline 平寨水库 & 44.88 & 31.38 & -8.33 & -8.45 & -3.86 & 92.44 & -12.29 & -6.72 & 20.81 & 19.08 & -10.15 \\
& \pm 5.99 & \pm 8.06 & \pm 1.68 & \pm 4.13 & \pm 0.93 & \pm 1.66 & \pm 3.09 & \pm 5.92 & \pm 3.29 & \pm 3.23 & \pm 2.43 \\
普定水库 & 39.11 & 41.62 & 0.49 & -26.48 & 22.38 & 75.29 & 1.64 & 5.47 & -19.48 & 22.05 & 10.08 \\
& \pm 4.25 & \pm 2.75 & \pm 2.22 & \pm 5.97 & \pm 7.16 & \pm 19 & \pm 3.74 & \pm 1.88 & \pm 8.96 & \pm 3.93 & \pm 6.55 \\
红枫湖水库 & 36.08 & 32.25 & -1.3 & 3.67 & 10.5 & 91.35 & 15.53 & -1.37 & 0.19 & 51.17 & 6.23 \\
& \pm 3.24 & \pm 3.92 & \pm 3.5 & \pm 6.4 & \pm 16.78 & \pm 5.32 & \pm 25.77 & \pm 2.29 & \pm 0.35 & \pm 12.87 & \pm 14.6 \\
\hline
\end{tabular}

方解石沉淀过程中 $\mathrm{Mg}^{2+}$ 可取代 $\mathrm{Ca}^{2+}$ 进人晶格, 因此水库表层水中方解石沉淀会改变 $\mathrm{Ca}^{2+} 、 \mathrm{Mg}^{2+}$ 的化学 

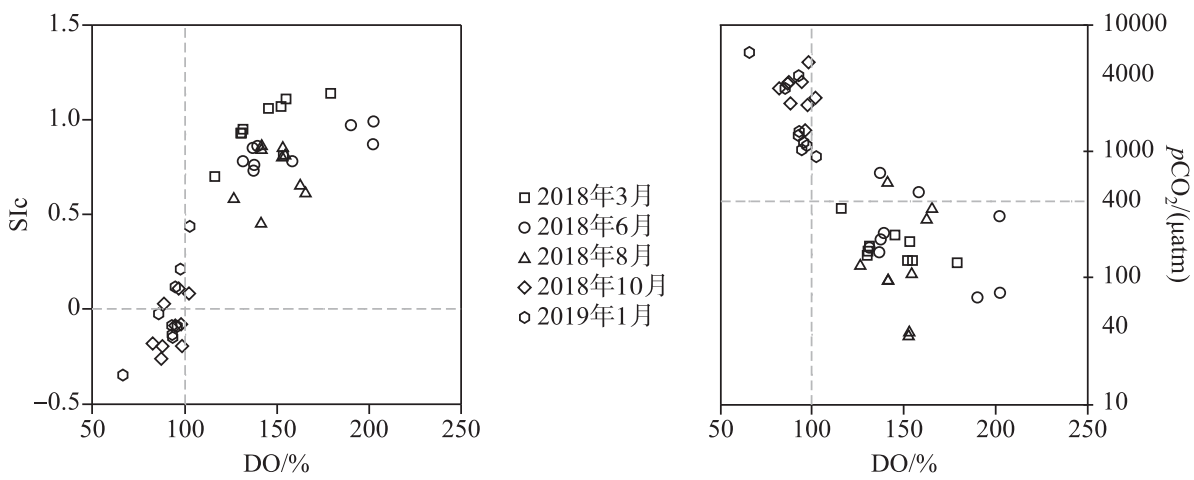

图 63 个水库表层水体 DO 含量分别与 SIc 和 $p \mathrm{CO}_{2}$ 的相关关系图 $(N=45)$

Fig.6 Scatterplot of DO content vs. SIc and $p \mathrm{CO}_{2}$ in surface water in three reservoirs $(N=45)$

计量关系, 如图 7 所示. 表层水体光合作用诱导方解石沉淀移除 $\mathrm{Ca}^{2+}$, 因此 $\mathrm{Mg}^{2+} / \mathrm{Ca}^{2+}$ 比值升高, 夏季平寨、普 定、红枫湖水库夏季表层和底层差值 $\Delta \mathrm{Mg}^{2+} / \mathrm{Ca}^{2+}$ 分别为 $0.13 \pm 0.05 、 0.31 \pm 0.02 、 0.24 \pm 0.01$, 因为其比值主要受 $\mathrm{Ca}^{2+}$ 的影响, 比值差值越大表明方解石沉淀作用越强, 这与方解石沉降通量较为一致 (见 3.3 节). 与 Katz 等 在以色列 Kinneret 湖研究结果一致 ${ }^{[19]}$. 在普定水库和红枫湖水库夏季底层水 $\mathrm{Mg}^{2+} / \mathrm{Ca}^{2+}$ 和冬季接近, 表明 $\mathrm{Mg}^{2+} 、 \mathrm{Ca}^{2+}$ 来源相对稳定.
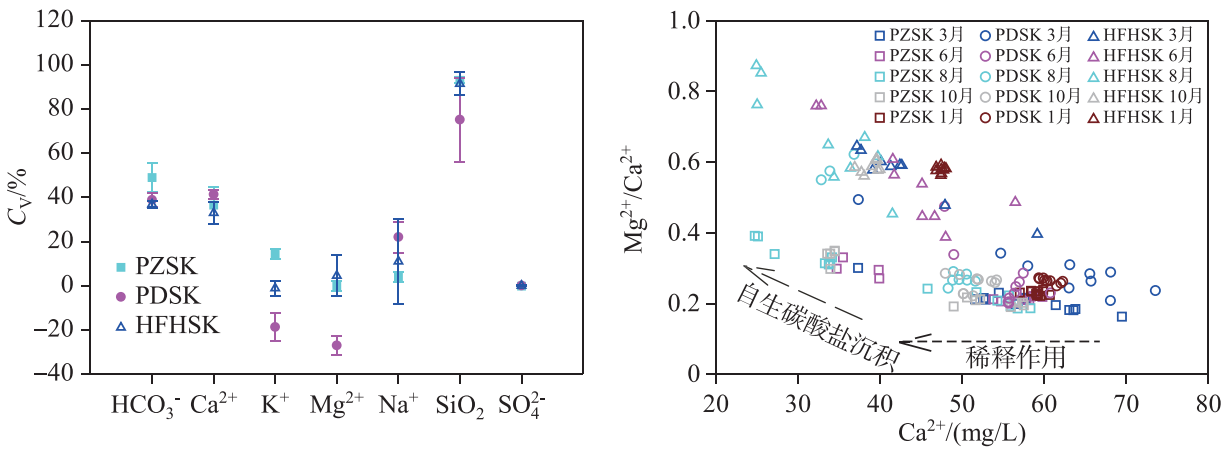

图 7 夏季主要离子变异系数, $\mathrm{Mg}^{2+} / \mathrm{Ca}^{2+}$ 比值与 $\mathrm{Ca}^{2+}$ 浓度的关系

Fig.7 The coefficient of variation for major ions in summer, scatterplot of $\mathrm{Mg}^{2+} / \mathrm{Ca}^{2+}$ and $\mathrm{Ca}^{2+}$ concentration

光合作用对营养元素的影响, 如图 8 所示, $\Delta \mathrm{HCO}_{3}^{-}$和 $\Delta \mathrm{Ca}^{2+} 、 \Delta \mathrm{NO}_{3}^{-} 、 \Delta \mathrm{SiO}_{2}$ 之间有正相关关系. $\Delta \mathrm{Ca}^{2+}$ ， $\Delta \mathrm{HCO}_{3}^{-}$接近 0.5 , 表明 $\mathrm{Ca}^{2+}$ 的移除主要受方解石沉淀的影响, $\Delta \mathrm{HCO}_{3}^{-}$浓度表现为平寨水库>普定水库>红枫湖 水库, 随富营养程度增加, 蓝绿藻占比增加, 蓝绿藻能够覆盖在水体表层进行光合作用, 可以直接利用大气
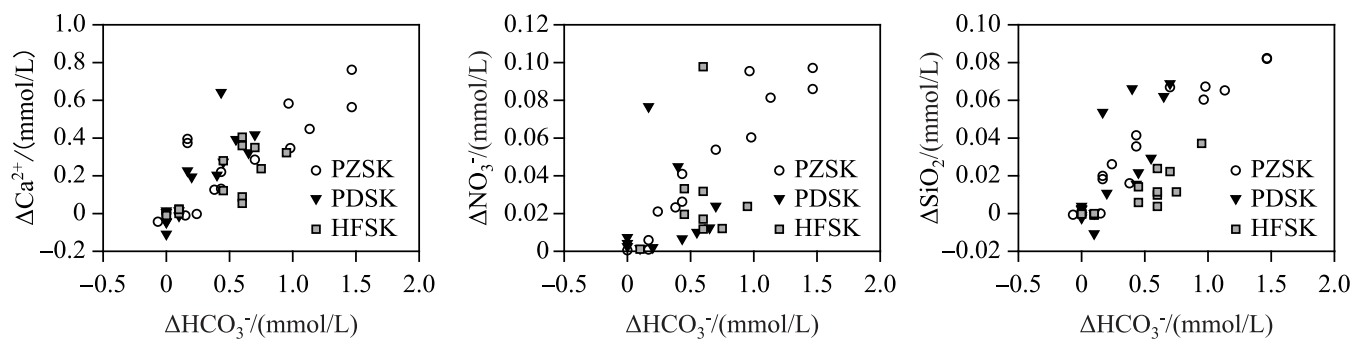

图 $8 \Delta \mathrm{HCO}_{3}^{-}$与 $\Delta \mathrm{Ca}^{2+} 、 \Delta \mathrm{NO}_{3}^{-} 、 \Delta \mathrm{SiO}_{2}$ 浓度之间的关系

Fig.8 Relationships between $\Delta \mathrm{HCO}_{3}^{-}$and $\Delta \mathrm{Ca}^{2+}, \Delta \mathrm{NO}_{3}^{-}, \Delta \mathrm{SiO}_{2}$ concentrations 
中 $\mathrm{CO}_{2}$ 作为碳源, 表明可能受生物群落结构的变化影响其 $\Delta \mathrm{HCO}_{3}^{-}$的变化幅度 ${ }^{[38]} . \Delta \mathrm{NO}_{3}^{-}$变化为平寨水库>普 定水库>红枫湖水库, 其不同藻类群落对营养元素氮的偏好吸收, 硅藻更偏好吸收磷, 蓝绿藻更偏好吸收 氮 ${ }^{[39]}$, 而富营养化程度高的红枫湖水库 $\Delta \mathrm{NO}_{3}^{-}$绝对变幅最低是因为红枫湖水库 $\mathrm{NO}_{3}^{-}$浓度低, 但是其相对百 分比降幅可达 $50 \% ; \Delta \mathrm{SiO}_{2}$ 的变化反映了硅藻对元素硅的吸收利用, 在平寨水库、普定水库硅藻占比相对较 高, 对元素硅的选择吸收也高, 在红枫湖水库以蓝绿藻为主, 对营养元素硅的吸收明显降低 ${ }^{[37]}$.

\section{3 水化学方法初步估算分层期方解石沉降通量}

由于混合期分层结束底层和表层水发生垂向剧烈混合, 夏季底层水可能受到部分稀释,因此利用春季 混合期湖水作为水库光合作用前的初始值, 计算夏季无机碳 (IC) 单位面积通量范围, 计算公式如下:

$$
F=\Delta X \cdot D \cdot 12 \cdot t / T_{\text {滞 }}
$$

式中, $F$ 为 IC 移除通量, $\Delta X$ 为初始值与表层浓度差值, $X$ 为 $\mathrm{Ca}^{2+}$ 或 $\mathrm{HCO}_{3}^{-}$浓度; $D$ 为表层光合作用影响深度, 高分辨率垂向监测数据表明, 光合作用主要控制的深度范围表层水体为 $3 \sim 5 \mathrm{~m}$, 所以选择表层水体深度为

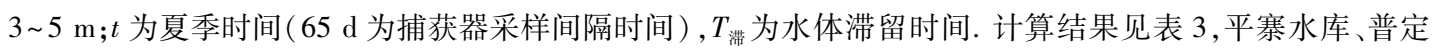
水库、红枫湖水库夏季实测沉积通量分别为 $0.63 \sim 0.86 、 1.12 \sim 1.66 、 0.15 \sim 0.44 \mathrm{t} /\left(\mathrm{km}^{2} \cdot \mathrm{d}\right), \mathrm{Ca}^{2+}$ 计算通量为 $0.31 \sim 0.64 、 0.35 \sim 0.99 、 0.09 \sim 0.29 \mathrm{t} /\left(\mathrm{km}^{2} \cdot \mathrm{d}\right), \mathrm{HCO}_{3}^{-}$计算通量为 $0.30 \sim 0.65 、 0.29 \sim 1.26 、 0.12 \sim 0.33 \mathrm{t} /\left(\mathrm{km}^{2} \cdot \mathrm{d}\right)$; 红 枫湖水库的沉降通量在计算范围内, 平寨、普定水库均部分超出计算通量范围. 一方面, 普定水库具有最强 的水动力条件, 平寨水库次之, 红枫湖水库最弱, 强水动力条件有更多的外源输人, 导致其实际沉降通量超 出计算通量范围, 垂向通量也显示普定水库随深度的增加而增加 (图 3), 表明普定水库有较多的外源输人; 平寨水库沿水库人口至大坝, 总的沉积通量逐渐降低, 进一步说明随着水动力条件减弱, 外源输人逐渐减 少; 另外一方面, 红枫湖水库地形较为平坦, 其水体滞留时间较长, 外源输人量对其影响相对较小, 所以导致 其外源输人差异对计算结果的影响, 而普定水库和平寨水库水体较深, 为河道型水库, 其水流侵蚀能够带来 更多的外源物质. 此外, 河水的 $\mathrm{Ca}^{2+}$ 与 $\mathrm{HCO}_{3}^{-}$要高于底层水库水体浓度, 水库底层水体没有受到河流是稀释 作用, 那么还存在底层水体往表层水体的扩散, 因此可能计算结果偏低; 魏榆的研究表明普定水库有较多的 外源有机质输人, 平寨水库次之, 红枫湖水库主要以内源为主 ${ }^{[36]}$. 因此, 可以利用水化学分层数据对无机碳 内源沉降通量进行估算, 并且能够得到较好的估算结果. 但在外源输人较多的河道型水库可能适用性还需 要进一步考虑外源输人贡献.

表 3 无机碳实测沉降通量和计算通量

Tab.3 Sediment deposition flux and calculated flux of inorganic carbon

\begin{tabular}{ccccccc}
\hline 水库 & $\begin{array}{c}\mathrm{IC}_{\text {夏 }} / \\
\left(\mathrm{t} /\left(\mathrm{km}^{2} \cdot \mathrm{d}\right)\right)\end{array}$ & $\begin{array}{c}\mathrm{OC}_{\text {夏 }} / \\
\left(\mathrm{t} /\left(\mathrm{km}^{2} \cdot \mathrm{d}\right)\right)\end{array}$ & $\begin{array}{c}\mathrm{IC}_{\text {总 }} / \\
\left(\mathrm{t} /\left(\mathrm{km}^{2} \cdot \mathrm{d}\right)\right)\end{array}$ & $\begin{array}{c}\mathrm{OC}_{\text {总 }} / \\
\left(\mathrm{t} /\left(\mathrm{km}^{2} \cdot \mathrm{d}\right)\right)\end{array}$ & $\begin{array}{c}\mathrm{IC}_{\text {夏算 }}\left(\mathrm{HCO}_{3}^{-}\right) / \\
\left(\mathrm{t} /\left(\mathrm{km}^{2} \cdot \mathrm{d}\right)\right)\end{array}$ & $\begin{array}{c}\mathrm{IC}_{\text {夏算 }}\left(\mathrm{Ca}^{2+}\right) / \\
\left.\left(\mathrm{t} /(\mathrm{km})^{2} \cdot \mathrm{d}\right)\right)\end{array}$ \\
\hline 平寨水库 & $0.74(0.63 \sim 0.86)$ & 0.29 & 2.11 & 0.71 & $0.30 \sim 0.65$ & $0.31 \sim 0.64$ \\
普定水库 & $1.36(1.12 \sim 1.66)$ & 0.67 & 3.55 & 1.48 & $0.29 \sim 1.26$ & $0.35 \sim 0.99$ \\
红枫湖水库 & $0.27(0.15 \sim 0.44)$ & 0.29 & 0.55 & 0.73 & $0.12 \sim 0.33$ & $0.09 \sim 0.29$ \\
\hline
\end{tabular}

全年实际沉积通量由于冬季光合作用会得到底层水体补给, 不能够估算全年沉积通量, 本文只讨论夏 季沉积通量. 一方面方解石的大量沉积能够裹挟有机质的沉降, 从而降低水体硬度和增加透明度. 另外一方 面喀斯特水生植物利用 $\mathrm{HCO}_{3}^{-}$转变为内源有机碳, 同时方解石也会沉淀, 因此方解石沉积通量可以反映 BCP 效应强度. 此外, 有研究显示, 方解石沉积能够与磷共沉淀而缓解富营养化和改善水质 ${ }^{[39]}$.

\section{4 结论}

1) 3 个不同库龄的喀斯特水库的水化学参数和主要阴阳离子结果显示, $\mathrm{Ca}^{2+}$ 和 $\mathrm{Mg}^{2+}$ 为主要阳离子, $\mathrm{HCO}_{3}^{-}$和 $\mathrm{SO}_{4}^{2-}$ 为主要阴离子. 平寨水库、普定水库水化学类型为 $\mathrm{Ca}-\mathrm{HCO}_{3}-\mathrm{SO}_{4}$, 红枫湖水库为 $\mathrm{Ca}-\mathrm{Mg}-\mathrm{HCO}_{3}-$ $\mathrm{SO}_{4}$ 类型, 水化学类型的差异主要是由不同小流域岩性、人类活动差异所造成的. 另一方面, 3 个水库水体离 子主要来源于碳酸对碳酸盐溶解作用,部分来源于硫酸溶解作用或石膏溶解. 
2) 水化学相关分析结果表明,春、夏两季 DO 与 SIc 呈极显著的正相关关系,而 DO 和 $p \mathrm{CO}_{2}$ 呈极显著的 负相关关系, 这表明方解石沉淀主要受藻类光合作用调控. 在夏季, $\mathrm{Mg}^{2+} / \mathrm{Ca}^{2+} 、 \mathrm{Sr}^{2+} / \mathrm{Ca}^{2+}$ 比值的降低表明藻 类光合作用诱导的碳酸盐沉淀不仅使得水体表层 $\mathrm{Ca}^{2+} 、 \mathrm{HCO}_{3}^{-} 、 \mathrm{Si}^{4+}$ 离子有所降低, 也吸收了水体中大量的 $\mathrm{C}$ 、 $\mathrm{N} 、 \mathrm{Si}$ 等生源要素. 因此, 喀斯特流域库区水化学的变化受藻类光合作用影响强烈.

3 ) 库区方解石沉降通量计算结果显示, 平寨水库、普定水库、红枫湖水库夏季实际沉积通量与基于 $\mathrm{Ca}^{2+} 、 \mathrm{HCO}_{3}^{-}$浓度变化的计算通量基本一致, 这表明利用水化学分层数据估算水库无机碳的沉降通量能够得 到较准确的结果.

\section{5 参考文献}

[ 1 ] Vörösmarty CJ, Sahagian D. Anthropogenic disturbance of the terrestrial water cycle. BioScience, 2000, 50(9) : 753-765. DOI: $10.1641 / 0006-3568(2000) 050[0753$ : ADOTTW $] 2.0 . \mathrm{CO} ; 2$.

[ 2 ] Kunz MJ, Wüest A, Wehrli B et al. Impact of a large tropical reservoir on riverine transport of sediment, carbon, and nutrients to downstream wetlands. Water Resources Research, 2011, 47(12) : W12531. DOI: 10.1029/2011 WR010996.

[ 3 ] Maavara T, Chen QW, Meter K et al. River dam impacts on biogeochemical cycling. Nature Reviews Earth \& Environment, 2020, 1(2) : 103-116. DOI: 10.1038/s43017-019-0019-0.

[ 4 ] Maavara T, Parsons CT, Ridenour C et al. Global phosphorus retention by river damming. PNAS, 2015, 112 (51): 15603-15608. DOI: 10.1073/pnas.1511797112.

[ 5 ] Mendonça R, Müller RA, Clow D et al. Organic carbon burial in global lakes and reservoirs. Nature Communications, 2017, 8: 1694. DOI: 10.1038/s41467-017-01789-6.

[ 6 ] Schleiss AJ, Franca MJ, Juez C et al. Reservoir sedimentation. Journal of Hydraulic Research, 2016, 54 (6) : 595-614. DOI: $10.1080 / 00221686.2016 .1225320$.

[ 7 ] Knoll LB, Vanni MJ, Renwick WH et al. Burial rates and stoichiometry of sedimentary carbon, nitrogen and phosphorus in Midwestern US reservoirs. Freshwater Biology, 2014, 59(11) : 2342-2353. DOI: 10.1111/fwb.12438.

[ 8 ] Gibbs RJ. Mechanisms controlling world water chemistry. Science, 1970, 170(3962) : 1088-1090. DOI: 10.1126/science. 170.3962.1088.

[ 9 ] Hu MH, Stallard RF, Edmond JM. Major ion chemistry of some large Chinese rivers. Nature, 1982, 298(5874) : 550553. DOI: $10.1038 / 298550 \mathrm{a} 0$.

[10] Torres MA, West AJ, Clark KE et al. The acid and alkalinity budgets of weathering in the Andes-Amazon system: Insights into the erosional control of global biogeochemical cycles. Earth and Planetary Science Letters, 2016, 450 : 381-391. DOI: 10.1016/j.epsl.2016.06.012.

[11] Zhang F, Jin ZD, Shi YW et al. Seasonal and spatial variations of water chemistry in Lake Qinghai and its influence by authigenic carbonate precipitation. Journal of Earth Environment, 2013, 4(3) : 1314-1321. DOI: 10.7515/JEE201303003. [张飞, 金章东, 石岳威等. 青海湖水化学的季节性和空间变化及其受自生碳酸盐沉淀的影响. 地球环境学报, 2013, 4(3): 1314-1321.]

[12] De Montety V, Martin JB, Cohen MJ et al. Influence of diel biogeochemical cycles on carbonate equilibrium in a Karst river. Chemical Geology, 2011, 283(1/2) : 31-43. DOI: 10.1016/j.chemgeo.2010.12.025.

[13] Hammes F, Verstraete W. Key roles of $\mathrm{pH}$ and calcium metabolism in microbial carbonate precipitation. Reviews in Environmental Science and Biotechnology, 2002, 1(1) : 3-7. DOI: 10.1023/A: 1015135629155.

[14] Nõges P, Cremona F, Laas A et al. Role of a productive lake in carbon sequestration within a calcareous catchment. Science of the Total Environment, 2016, 550: 225-230. DOI: 10.1016/j.scitotenv.2016.01.088.

[15] Rogerson M, Pedley HM, Middleton R. Microbial influence on macroenvironment chemical conditions in alkaline (tufa) streams: Perspectives from in vitro experiments. Geological Society, London, Special Publications, 2010, 336( 1 ) : 65-81. DOI: $10.1144 / \mathrm{sp} 336.5$.

[16] Gammons CH, Babcock JN, Parker SR et al. Diel cycling and stable isotopes of dissolved oxygen, dissolved inorganic carbon, and nitrogenous species in a stream receiving treated municipal sewage. Chemical Geology, 2011, 283(1/2) : 44-55. DOI: 10.1016/j.chemgeo.2010.07.006.

[17] Rogerson M, Pedley HM, Wadhawan JD et al. New insights into biological influence on the geochemistry of freshwater car- 
bonate deposits. Geochimica et Cosmochimica Acta, 2008, 72(20) : 4976-4987. DOI: 10.1016/j.gca.2008.06.030.

[18] Liu ZH, Liu XL, Liao CJ. Daytime deposition and nighttime dissolution of calcium carbonate controlled by submerged plants in a Karst spring-fed pool: Insights from high time-resolution monitoring of physico-chemistry of water. Environmental Geology, 2008, 55(6) : 1159-1168. DOI: 10.1007/s00254-007-1062-6.

[19] Katz A, Nishri A. Calcium, magnesium and strontium cycling in stratified, hardwater lakes: Lake Kinneret (Sea of Galilee), Israel. Geochimica et Cosmochimica Acta, 2013, 105: 372-394. DOI: 10.1016/j.gca.2012.11.045.

[20] Liu ZH, MacPherson GL, Groves C et al. Large and active $\mathrm{CO}_{2}$ uptake by coupled carbonate weathering. Earth-Science Reviews, 2018, 182: 42-49. DOI: 10.1016/j.earscirev.2018.05.007.

[21] Tranvik LJ, Downing JA, Cotner JB et al. Lakes and reservoirs as regulators of carbon cycling and climate. Limnology and Oceanography, 2009, 54(6part2) : 2298-2314. DOI: 10.4319/lo.2009.54.6_part_2.2298.

[22] Wang SJ, Li YB, Li RL. Karst rocky desertification: Formation background, evolving and comprehensive taming. Quaternary Sciences, 2003, 23(6) : 657-666. [王世杰, 李阳兵, 李瑞玲. 喀斯特石漠化的形成背景、演化与治理. 第四纪 研究, 2003, 23(6) : 657-666.]

[23] Han GL, Liu CQ. Hydrogeochemistry of rivers in Guizhou Province, China: Constraints on crustal weathering in Karst terrain. Advances in Earth Science, 2005, 20 (4) : 394-406. [韩贵琳, 刘丛强. 贵州喀斯特地区河流的研究一一碳酸盐 岩溶解控制的水文地球化学特征. 地球科学进展, 2005, 20(4) : 394-406.]

[24] Li GR, Liu CQ, Chen C et al. Dissolve inorganic carbon and its carbon isotope composition in cascade reservoir of the Maotiao river during summer and autumn. Environmental Science, 2009, 30 (10): 2891-2897. DOI: 10.13227/j. hjkx. 2009.10.011. [李干蓉, 刘丛强, 陈椽等. 猫跳河流域梯级水库夏-秋季节溶解无机碳 ( DIC) 含量及其同位素组成 的分布特征. 环境科学, 2009, 30(10): 2891-2897.]

[25] Peng X, Liu CQ, Wang BL et al. Spatiotemporal characteristics and diffusion flux of partial pressure of dissolved carbon dioxide $\left(\mathrm{CO}_{2}\right)$ in the river-reservoir system as exemplified by the Liuchonghe River, Hongjiadu Reservoir and Hongfenghu Lake. Earth and Environment, 2013, 41(2) : 97-103. [彭希, 刘丛强, 王宝利等. 河流-水库体系水体表层 $\mathrm{pCO}_{2}$ 时空变化特征及其扩散通量一一六冲河、洪家渡水库、红枫湖为例. 地球与环境, 2013, 41(2): 97-103.]

[26] Long SX, Chen C, Guo Y et al. Phytoplankton's characteristics of community structure and eutrophication in Hongfeng lake reservoir of GuiZhou. Environmental Monitoring in China, 2013, 29(1): 23-29. [龙胜兴, 陈椽, 郭云等. 红枫湖水库 水体富营养化及浮游植物群落结构特征. 中国环境监测, 2013, 29(1) : 23-29.]

[27] Hou YL, An YL, Wu QX et al. Hydrochemical characteristics in the Sanchahe river basin and the possible controls. Resources and Environment in the Yangtze Basin, 2016, 25(7) : 1121-1128. DOI: 10.11870/cjlyzyyhj201607014. [侯神 亮, 安艳玲, 吴起金等. 贵州省三岔河流域水化学特征及其控制因素. 长江流域资源与环境, 2016, 25(7): 1121-1128.]

[28] Qian HT, Wang SJ, Yan FZ et al. Karst development models and reservoir anti-seepage design in a hydro-junction construction site in Qianzhong district. Hydrogeology and Engineering Geology, 2008, 35(4) : 51-57. [ 钱海涛, 王思敬, 严 福章等. 黔中水利枢纽一期工程区岩溶发育模式及水库防渗研究. 水文地质工程地质, 2008, 35(4): 51-57.]

[29] Zhu CC, Li QH, Chen WS et al. Metazooplankton community structure characteristics and its water quality indicating function in Puding Reservoir of Guizhou Province. Jiangsu Agricultural Sciences, 2019, 47(3) : 273-277. [ 朱冲冲, 李秋华, 陈文生等. 贵州普定水库后生浮游动物群落结构特征及其水质指示作用. 江苏农业科学, 2019, 47(3) : 273-277.]

[30] Xiang P, Wang SL, Lu WQ et al. Distribution and retention efficiency of nitrogen and phosphorus in cascade reservoirs in Wujiang river basin. Earth and Environment, 2016, 44(5): 492-501. [向鹏, 王仕禄, 卢玮琦等. 乌江流域梯级水库 的氮磷分布及其滞留效率研究. 地球与环境, 2016, 44(5): 492-501.]

[31] Xiao J, Wang BL, Zhang HT et al. Succession of phytoplankton functional groups in the Wujiang river-reservoir system and its environmental impact factors identification. Earth and Environment, 2019, 47(6): 829-838. [肖晶, 王宝利, 张海涛 等. 乌江河流-水库体系浮游植物功能群演替及其环境影响因子辨识. 地球与环境, 2019, 47(6): 829-838.]

[32] Parkhurst DL, Appelo CAJ. User's guide to PHREEQC version 3-A computer program for speciation, batch-reaction, one-dimensional transport, and inverse geochemical calculations. 1999.

[33] Zhao M, Zeng C, Yang R et al. Seasonal variation of sulfur isotope in dengzhanhe Karst spring of Puding, Guizhou. Journal of Earth Sciences and Environment, 2012, 34(3):83-88. [赵敏, 曾成, 杨睿等. 贵州普定灯戔河岩溶泉的硫同位 素季节变化特征. 地球科学与环境学报, 2012, 34(3):83-88.] 
[34] Jiang YK, Liu CQ, Tao FX. Sulfur isotope composition characters of Wujiang river water in Guizhou Province. Advances in Water Science, 2007, 18(4): 558-565. [蒋颖鬼, 刘丛强, 陶发祥. 贵州乌江水系河水硫同位素组成特征研究. 水科 学进展, 2007, 18(4): 558-565.]

[35] Gabitov RI, Sadekov A, Leinweber A. Crystal growth rate effect on Mg/Ca and $\mathrm{Sr} / \mathrm{Ca}$ partitioning between calcite and fluid: An in situ approach. Chemical Geology, 2014, 367: 70-82. DOI: 10.1016/j.chemgeo.2013.12.019.

[36] Wei Y, Yang CP, Yan H et al. Coupled cycling of carbon and silica in Karst reservoirs: Insights from Hongfeng lake, Puding reservoir and Pingzhai reservoir. Earth and Environment, 2020, 48(1): 1-9. [魏榆, 杨昌平, 晏浩等. 喀斯特水库 碳、硅耦合循环: 以红枫湖、普定水库和平寨水库为例. 地球与环境, 2020, 48(1): 1-9. ]

[37] Han CH, Sun HL, Wei Y et al. Spatiotemporal variations of hydrochemistry in Karst dammed rivers and carbon fertilization effect of biological carbon pump: A case study of Pingzhai Reservoir and Lake Hongfeng in Guizhou Province. J Lake Sci, 2020, 32(6) : 1683-1694. DOI: 10.18307/2020.0610. [韩翠红, 孙海龙, 魏榆等. 喀斯特筑坝河流中生物碳㫤效应 的碳施肥及对水化学时空变化的影响——以贵州平寨水库及红枫湖为例. 湖泊科学, 2020, 32(6): 1683-1694.]

[38] Xu YG, Li AJ, Qin JH et al. Seasonal patterns of water quality and phytoplankton dynamics in surface waters in Guangzhou and Foshan, China. Science of the Total Environment, 2017, 590/591: 361-369. DOI: 10.1016/j.scitotenv.2017. 02.032 .

[39] Müller B, Meyer JS, Gächter R. Alkalinity regulation in calcium carbonate-buffered lakes. Limnology and Oceanography, 2016, 61(1) : 341-352. DOI: 10.1002/lno.10213. 